\title{
Leasing as an Alternative Form of Financing within Family Businesses: The Important Advisory Role of the Accountant
}

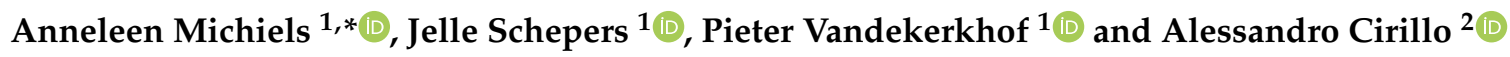 \\ 1 Research Center for Entrepreneurship and Family Firms, Hasselt University, 3500 Hasselt, Belgium; \\ jelle.schepers@uhasselt.be (J.S.); pieter.vandekerkhof@uhasselt.be (P.V.) \\ 2 Department of Economy Foggia, University of Foggia, 71122 Foggia, Italy; alessandro.cirillo@unifg.it \\ * Correspondence: anneleen.michiels@uhasselt.be
}

check for

updates

Citation: Michiels, A.; Schepers, J.; Vandekerkhof, P.; Cirillo, A. Leasing as an Alternative Form of Financing within Family Businesses: The Important Advisory Role of the Accountant. Sustainability 2021, 13, 6978. https://doi.org/10.3390/ su13126978

Academic Editors: Jennifer Martínez-Ferrero and Marc A. Rosen

Received: 3 May 2021

Accepted: 11 June 2021

Published: 21 June 2021

Publisher's Note: MDPI stays neutral with regard to jurisdictional claims in published maps and institutional affiliations.

Copyright: (c) 2021 by the authors. Licensee MDPI, Basel, Switzerland. This article is an open access article distributed under the terms and conditions of the Creative Commons Attribution (CC BY) license (https:/ / creativecommons.org/licenses/by/ $4.0 /)$.

\begin{abstract}
Although leasing can be an interesting financing option from an economic point of view, family businesses are found to be less prone to lease. In this study, we examine the view of the external accountant on leasing as an alternative form of financing within family businesses. After all, as the most trusted advisor, the accountant likely has a significant influence on the financial decisions that are taken within private family businesses. By means of an exploratory qualitative study, we examine what factors influence the advice for a particular financing option and the accountant's recommendation to lease or not to lease within family businesses. By combining the extant literature with the results of this exploratory qualitative research, we formulate propositions that form fruitful avenues for future research.
\end{abstract}

Keywords: family businesses; financing; leasing

\section{Introduction}

Family businesses, unlike other businesses, base their financial decisions not only on economic factors but also on noneconomic factors [1,2]. They consider, among other things, their identity, the survival of the family dynasty, family influence and control, their emotions, and their preferred values [3]. For this reason, family firms often tend to prioritize the long-range implications and impact of their (financial) decisions in order to safeguard the long-term sustainability of their family business [4]. There is consensus in family business literature that all financial decisions in family firms are thus not only driven by financial motives but also in a large part by a diverse set of family owners' nonfinancial motives. These motives can be synthesized in the preservation of the different aspects of the family's socioemotional wealth (SEW) [3]. Therefore, when making financing decisions, external debt is likely preferred over external equity within family firms [5-9]. By opting for external debt, family owners retain control and ownership within their firms [5], as these options contribute to the preservation of their SEW. Raising equity by introducing nonfamily ownership into the company by contrast reduces the company's shareholding and weakens their control [6], which jeopardizes emotional endowment. Thus, in order to understand the choice between financing options such as external debt versus bringing external nonfamily ownership into the company, a family firm's risk aversion should also be taken into account $[10,11]$. Moreover, given their risk aversion, family firms are generally characterized by an overall lower debt ratio [10] resulting in more family control as it limits financial institutions to monitor from the outside [12]. In sum, current family business literature agrees that SEW preservation highly influences the financing decisions in family firms.

Even though risk aversion plays a major role in family firms' funding decisions, debt financing is the most preferred source of funding when such financial needs occur [13]. However, the general interest for alternative forms of financing such as leasing, factoring, and crowdfunding is rising. A major advantage of leasing is the avoidance of investment. 
With a lease, the lessee can use the asset without having to invest any money [14]. Moreover, leasing can be tailored to cashflow needs, making it a flexible way to finance assets [12,14]. Therefore, the European leasing industry continues to grow, and in 2018, the portfolio of leased assets reached 832.6 billion euros compared to 755.4 billion euros in 2015 [15]. Unfortunately, existing studies do not reveal much about the use of these alternative forms of financing within the specific context of family businesses [16], even though it appears to be interesting for family businesses to lease [12]. Although leasing can be economically efficient, family businesses are driven by their SEW preservation in such decisions. They may be less likely to lease an asset because they generally prefer to buy the asset in order to accumulate wealth but also to increase the control over firm assets to further guarantee the long-term sustainability of their business [12]. In sum, little is known on the family firm's strategic decision-making process when considering and evaluating leasing as an alternative form of finance. In this paper, we therefore aim to investigate the leasing decision in family firms by specifically looking at the role of the family firm's accountant in this process. In particular, this study seeks to address how the advisory role of the accountant might influence the family firm's strategic financing decisions.

Several studies have highlighted the crucial role of family firm advisors in the strategic decision making of family firms (e.g., $[17,18])$. More specifically, when making financing decisions, family firms often turn to different sources of advice to discuss challenges and to gain a fresh view on the sustainability of their business. They seek the advice of both internal and external advisors to adjust or modify their opinion $[19,20]$. As family firms often lack in-house financial and accounting skills, they mostly rely on the advice of an external accountant to make their financing decisions [21]. According to Hanot (2012), at least $60 \%$ of all companies use an external accountant as a privileged advisor. For family firms, this number even increases to $94 \%$ [22]. Given that accountants are the most effective and widely used source of external advice for family firms $[17,22]$, this study aims to investigate the role of the accountant in the family firms' decision-making process on whether or not to use leasing as an alternative form of finance. To accomplish this aim, the authors perform a qualitative multiple case study by conducting semi-structured interviews with external accountants who advise family firms in their financing decisions. We rely on a qualitative research method, as this allows "how" and "why" questions to be answered $[23,24]$. The analysis of the multiple cases resulted in several theoretical propositions that can be pursued in future studies.

We contribute to the current literature in three ways. First, we contribute to the literature on advising family firms by explicitly examining how the external accountant intervenes in the family's financing decision making. More specifically, our study uncovers how external accountants provide advice to family firms, what family firm-specific elements they take into account when providing their advice, and also what type of advice they generally provide when it comes to alternative financing decisions in family firms. Second, our study contributes to the literature on financial decision making in family firms by adding an important element to the discussion, namely the advisory role of the external accountant. While SEW perspectives, agency and pecking-order theory are generally used to understand family firm's financial decisions, our study makes an important contribution to the field by demonstrating how the external accountant plays a prominent role in steering family firms' financial decisions and ultimately their financial sustainability [25]. Third, our study contributes to the finance literature on leasing. The current literature on leasing fails to appropriately account for the idiosyncratic character of family firms. By using a SEW perspective, this study answers several calls in the leasing literature [16] to take into account the importance of control retention, risk aversion, and nonfinancial values and goals in the owners' /managers' financial decision making. Furthermore, this study focuses on leasing as an alternative form of financing, but a trade-off with the bank loan is also made $[5,6,8]$. This provides a more comprehensive overview and can contribute to research that takes into account the noneconomic factors influencing the financing decisions of family firms $[5,7]$. 
The remainder of this article is structured as follows: We proceed with a description of the existing literature on accountants, family businesses, and leasing. After describing the methodology and presenting the results, we formulate the propositions. The paper ends with a discussion and conclusions.

\section{Theoretical Framework}

\subsection{Financing Decisions in Family Businesses}

In the context of private firms, capital structure decisions often depend on preferences and goals [26,27] of the owner/manager as they are frequently the main decision maker [28]. Considering family-owned firms poses even more importance on such goals. In fact, financing decisions in those firms integrate two competing perspectives [29]: the economic one, grounded on the convenience of choosing a certain form of capital based on its economic costs such as interest rate, fiscal advantages, and impact on the balance sheet; as well as the noneconomic one, embedded into the considerations of nonfinancial aspects such as transgenerational focus, risk propensity, and ownership retention.

The coexistence of those perspectives makes family firms unique with respect to financial behavior [16]. At its core, two theoretical perspectives, borrowed from the finance framework, are useful to contextualize the cited issue: the pecking-order theory (POT) and the trade-off theory (TOT). POT indicates that, due to information asymmetries, firms use different sources of capital based on a specific order of preferences: internal financing (e.g., retained earnings), debt capital (e.g., short-term and long-term borrowing), and new equity capital [30]. TOT states that firms are willing to model their optimal capital structure by balancing the tax benefits of debt and the costs of financial distress [31]. The previous literature stressed the importance of POT for private family firms because they sustain more severe costs related to information asymmetries: this influences their financing decisions and puts retained earnings at the top of their preferences [6,32].

Scholars advocate that the exposed finance framework should be complemented with specific family theoretical insights [33]. In this sense, SEW appears as a promising one. The SEW perspective refers to the nonfinancial aspects that are taken into account when making decisions [34]. It concerns elements that satisfy the nonfinancial needs of the family, such as their identity, the use of their influence, and the continuation of their dynasty [34], which makes them want to maintain control and avoid things that could jeopardize their socioeconomic well-being [16].

Integrating SEW considerations into POT theory is crucial. In fact, when protecting emotional endowment becomes an objective itself, private family firms tend to avoid equity capital. This finds support in the fact that the equity form of financing implies a dilution or a (partial/full) loss of family control, in light of the increased power of new nonfamily shareholders. This is at odds with the family's objective to not jeopardize family influence. However, even if external finance is labeled as "non-control-diluting security" [35], it might also lead to a potential dilution of family control and influence because of financial risk that comprises bankruptcy possibility and creditors' increased power. It is worth noting that both equity and debt financing have the potential to move family owners' focus from SEW-related objectives to financial ones [33]: that is why family firms prefer to rely upon internally generated funds with no third parties' influences and a stringent emphasis on SEW-related goals.

In light of the exposed framework, we integrate the family research domain by offering a new perspective on leasing as an alternative form of financing. Leasing appears particularly suitable for private family firms because it allows the family to maintain control over the company and avoid borrowing debt capital from a financial institution; therefore, no additional external supervision is considered [12]. Despite these benefits, this type of financing is not as common as one might argue due to the level of technical knowledge required to properly evaluate the leasing option. This motive pushes family firms to involve an external accountant in order to discriminate between leasing and its alternatives. Within this study, by taking the perspective of external accountants that were 
interviewed, we thus contemplate three pillars: technical contingencies, family goals, and relational aspects.

\subsection{Alternative Forms of Financing for Family Firms: The Role of Leasing}

A lease can be described as a contractual agreement between two parties whereby the lessee, in return for a series of periodic payments to the lessor, may use assets for a predetermined period of time $[12,36]$. Thus, the tenant is entitled to the use of the asset but also to the economic benefits obtained through the use [36]. A distinction can be made between a financial lease and an operating lease $[14,36,37]$.

With a financial lease, the property rights are in the hands of the lessee but also the property risks, such as loss or damage, which makes this type of lease riskier than an operating lease [14,37]. Because in financial leasing the asset is considered as property, it is recorded by the lessee as firm asset $[14,36]$. For the lessor, the finance lease is reflected in the balance sheet as a receivable [36]. In contrast to an operating lease, a finance lease involves a purchase option that allows the lessee to purchase the asset at a negotiated price at the end of the lease agreement [14].

With an operating lease, the lessor assumes all risks [14]. Therefore, the asset is not recorded as a firm asset on the balance sheet, but the lease payments are recorded as a rental cost in the income statement [36]. As a result, operating leasing is also known as 'off-balance sheet financing' [14]. Since the lessor remains the owner of the asset, the operating lease is also seen as a secured loan [12,38]. Under this type of lease, the lessee is only entitled to use the asset and is also restricted in making changes or improvements [37]; the lessee can only make these if there is permission from the lessor [14].

Regardless of the choice between financial or operating leasing, Bolea and Cosma [14] argue that there are numerous advantages to leasing, with the avoidance of investment as one of the most important benefits. With a lease, the lessee can use the asset without having to invest a whole sum of money. Moreover, no mortgage is applicable, which provides convenience. In general, there are fewer formalities than when borrowing from a financial institution, and leasing can be tailored to cash flow needs, making it a flexible form of financing [12]. Leasing could be a possible alternative form of financing, but family businesses are less inclined to use it unless they have more influence, have growth opportunities, or want to retain liquidity [12]. According to Di Giuli et al. [39], its use also increases across generations but also when the family business operates with an external CFO or shareholder.

\subsection{The Importance of the External Accountant in (Financial) Decision-Making}

Having introduced the family complexity, driven by the unique intermingling between business and family interests [40], into the financial decisions domain, we now turn our attention to considering such complexity when external accountants serve as advisors.

As a nonfamily member, an advisor is best equipped to manage family complexities coming from blending financial and SEW-related goals and to work at the level of family, company, and property [17]. Family firms thus attach great importance to working with an advisor who is reliable [41], but also honest, sincere, and loyal [42]. Moreover, the advisor should have a relationship with the family business [18]. If advisors can open up themselves, they are able to win the trust of the family [43]; the more trust there is, the more influence the advisor has on the company [17].

Looking at the multitude of external advisors available for family firms, accountants assume a relevant role. Accountants are responsible for providing financial information in most companies and playing a major role in related decision-making processes [44], especially when it comes to investments. This is because they are involved in explaining the financial statements, in preparing budgets, and in identifying measurable outcomes [44].

The necessity of an external accountant streams from the "limited talent pool" of family talents where, very often, financial as well as accounting knowledge and skills are lacking [45]. Not surprisingly, accountants are one of the main external advisory sources to 
fulfil the role of the most trusted advisor [46]. In total, $60 \%$ of companies use the accountant as a privileged advisor and $94 \%$ for family businesses in particular [22]. They also tend to use these external accountants to help them in their choice of external forms of finance [21].

Even though their importance in financing decision-making processes is confirmed, we know little about the specific impact an accountant might have in guiding a family firm when considering the possibilities of financing forms. Therefore, we use a qualitative research approach to detect how accountants perceive that they can guide family firms in specific finance-related decisions, with a specific focus on the leasing options.

\section{Methodology}

The aim of this study is to find out how the advisory role of the accountant might influence the family firm's strategic financing decisions, in particular with regard to leasing as a possible alternative form of financing. Because there is no combined research yet on accountants and leasing, it is interesting to conduct a qualitative research. This is interesting because it allows "how" and "why" questions to be solved [23,24] but also because there are still few qualitative, case-based studies with regard to this specific topic [16]. Thus, a grounded theory method is applied to build theoretical propositions [47]. This is conducted using an exploratory multiple case study to understand how something takes place [24]. Using multiple cases ensures that the results are more robust and based more profoundly on alternating empirical evidence [24]. A (multiple) case study allows for new insights or clarification [47] regarding the advising of leasing by accountants to family businesses.

\subsection{Data Collection}

The data are collected by conducting five semi-structured interviews; the questions and their order are determined in advance, but there is also room to elaborate on certain topics, questions, and answers during the interview itself [48,49]. Interviews were chosen because this is an efficient way to collect rich, empirical data [47] and to obtain a broad understanding [24] of what accountants consider important in choosing leasing as a form of financing for family businesses.

In grounded theory, the number of cases is not set. It determined by the level of saturation; if theoretical saturation is reached, enough interviews have been conducted [50]. As our research focus is quite narrowly defined [51], the point of theoretical saturation, in which no new dimensions or relationships were emerging, was reached after five in-depth interviews.

We selected acknowledged accountants in this study, who met predetermined criteria. For example, the accountant must be active as an external accountant (1). This means that a company outsources its accounting tasks to this person or the office where the accountant is employed [52]. In addition, the accountant must work with family businesses (2) and have some prior knowledge of leasing (3). In this paper, a firm is seen as a family business if: (1) at least $50 \%$ of the shares are owned by the family, and the family is responsible for the management of the company, or (2) at least $50 \%$ of the shares are owned by the family, the company is not family managed, but the CEO perceives the firm as a family firm. This definition is based on the most commonly selected criteria of ownership and management control [40] and the CEO's perception of being a family firm [53]. It is important that the respondents meet these conditions in order to collect relevant information needed to answer the proposed research question. In order to promote the validity of the data, different data sources were used, which resulted in triangulation [48]. This also ensures that findings can be more conclusive and accurate [54]. More specifically, we consulted secondary data sources apart from our semi-structured interviews to triangulate our data. We used publicly available data from Belfirst, gathered by Bureau van Dijk, to profile each accountancy office. Second, we used information from a Belgian accounting database, the $\mathrm{IAB}$, to obtain additional background information on the participants of our qualitative study. Some descriptives of our respondents are summarized in Table 1 below. 
Table 1. Overview of respondents.

\begin{tabular}{ccccc}
\hline Accountant & Age & Education & $\begin{array}{c}\text { Experience as } \\
\text { External } \\
\text { Accountant }\end{array}$ & $\begin{array}{c}\text { Size of the } \\
\text { Office }\end{array}$ \\
\hline A1 & 40 & $\begin{array}{c}\text { Bachelor Accounting-Tax and } \\
\text { Master Commercial Sciences }\end{array}$ & 15 years & $\begin{array}{c}4 \text { partners and } \\
40 \text { employees }\end{array}$ \\
\hline A2 & 63 & $\begin{array}{c}\text { Bachelor Accounting-Tax and } \\
\text { Master Fiscal Law }\end{array}$ & 34 years & $\begin{array}{c}\text { 2 partners and } \\
12 \text { employees }\end{array}$ \\
\hline A3 & 28 & Bachelor Accounting and Tax & 6 years & 1 partner \\
\hline A4 & 39 & $\begin{array}{c}\text { Bachelor and Master in } \\
\text { Applied Economic Sciences }\end{array}$ & 7 years & 1 partner \\
\hline A5 & 40 & Bachelor Accounting and Tax & 8 years & $\begin{array}{c}1 \text { partner and 3 } \\
\text { employees }\end{array}$ \\
\hline
\end{tabular}

\subsection{Data Analyses}

The recorded interviews, lasting on average about $45 \mathrm{~min}$, are all transcribed and coded. In order to organize the collected data, a case study database is created in which the data sources are tracked and organized so that they can be easily retrieved later in the research. This ensures that the research becomes more reliable [24]. The acquired data are reduced and categorized in order to obtain a clear overview of possible similarities [24]. The qualitative data is analyzed using an iterative process; going back and forth between the data [24]. By gaining insights between different cases, similarities and differences can be identified [55]. The results of this qualitative output are used to formulate theoretical propositions and thus not to statistically generalize assumed relationships [56].

\section{Results and Discussion}

This study provides an answer to the question: "What is the role of the accountant in the family firms' decision-making process to use leasing as an alternative form of finance?" The propositions made in this section are formulated by comparing the literature study with the findings from the interviews. All propositions can be extrapolated into three distinct categories as shown in the summarizing conceptual framework (see Figure 1 below): relational aspects; family goals and attributes; and technical contingencies. Each category with belonging propositions is now further discussed in detail.

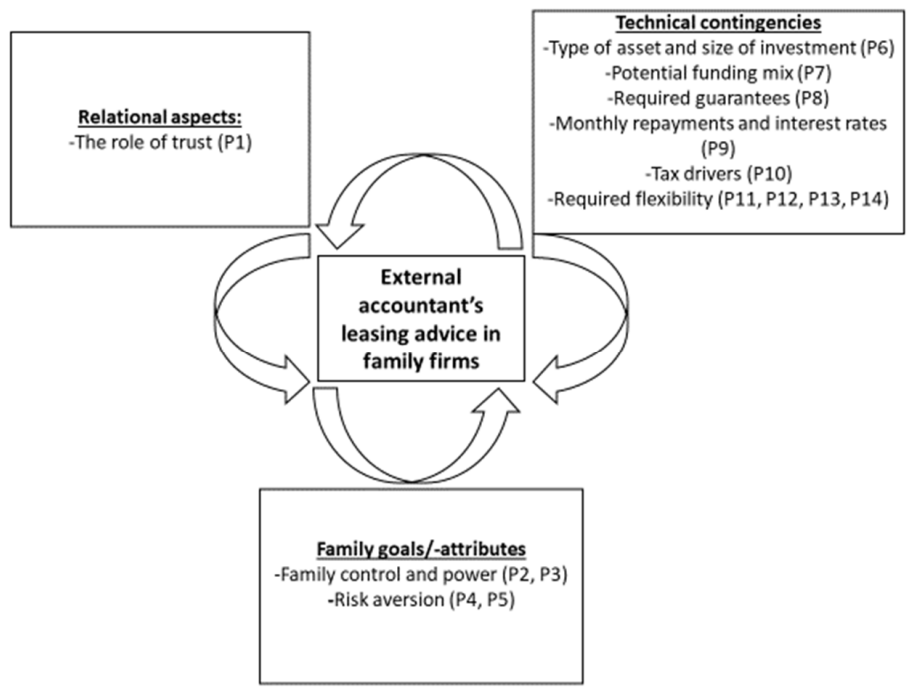

Figure 1. Conceptual framework on the role of the external accountant's leasing advice in family firms. 


\subsection{Relational Aspects}

In family firm literature, accountants are often qualified as the most trusted advisor by companies [57]. They can offer a certain expertise that employees within a family business often do not have [21]. This expertise is related to financial and accounting aspects [21,45]. Our results show that family businesses indeed trust on their external accountant to obtain more information and seek advice with regard to their financial questions.

"When we are faced with a problem of how to finance, we do advise on the best form of financing to follow. But sometimes we get the question 'should we lease?', 'should we invest?'“. (A3)

"The entrepreneur says: Look, a certain amount of funding is needed for a certain purchase or we temporarily need extra money in the company". (A5)

Although it was indicated that the company would approach the accountant on its own initiative if they needed advice about financing a particular investment or an asset, A3 indicates that sometimes the accountancy firm also reacts proactively if the situation within a company is not optimal. They then bring in their expertise and propose initiatives to adjust the situation. All five respondents claim that they have a certain influence on the financial decisions in family firms. However, they make it clear that they cannot exert the same influence in every company.

"It depends a bit on the relationship with the customer, but let's say that with the majority of customers, the decision about financing the business lies with us". (A2)

Like respondent $\mathrm{A} 2$, the other accountants indicated that the degree of influence on financial decisions depended on the company and the client-accountant relationship. Strike [17] previously concluded that the more trust the company has in the advisor, the more influence it can exert on the company. Since the accountant is most often chosen as trusted advisor [22,46], the first proposition is as follows:

Proposition 1 (P1). Accountants tend to be the main advisory source when family firms need guidance and support in their financial decision-making, with the trust relationship as main driver for family firms to determine the level of influence the accountant has on the financial decisions that are taken.

\subsection{Family Goals and Attributes}

Family firm literature often emphasizes that family goals and attributes such as the intent to retain control as well as risk-aversion play a major role in their financing decisionmaking process $[5,10,11]$. As the following propositions show, these factors are taken into account by the accountant when proposing a form of financing but are not decisive in their preference for a possible financing option.

\subsubsection{Maintaining Control}

Only A4 indicates that wanting to retain control is a factor that plays a significant role in advising a particular form of financing for family businesses.

"In family firms, I don't think you often get financing proposals where outsiders would get control or participation rights in the firm". (A4)

Molly et al. [58] concluded that family businesses do not want to reduce the control they have. However, the interviews show that for the other four accountants, this factor is not decisive in their recommendation of financing. A1 said he does not consider retaining control as the deciding aspect when advising and selecting a particular form of financing option. A2 agrees and A3 claims that mainly the amount of power granted to an external party plays a decisive role. According to A5, it also depends on what expertise is attached to the funding. In addition, he explicitly confirmed that control is less and less prevalent in family businesses. 
"We see more and more that the control, also in family businesses, is less and less important. Certainly, with the Covid-19 situation we currently operate in, it would sometimes be useful if other partners could say 'I'll buy you out and continue the business'. Because continuing to pass it on to the next generation is certainly not always evident". (A5)

"Yes, that is being looked at, but it is not about financing. The reason for attracting an external financier would then rather be about how much power you give to such a person. Then it would be less about the financing itself". (A3)

The second proposition is based on this and indicates that for accountants, maintaining control is not a decisive factor in proposing a particular financing.

Proposition 2 (P2). Accountants do not tend to consider the family firms' desire to maintain control as a main driver in advising financing options but rather the amount of power granted to the financing party is an important aspect that is to taken into consideration.

Since the literature suggests that family businesses are less likely to lease [12], it is interesting to zoom in on whether the pursuit of family control might play a role when accountants opt to recommend leasing as an alternative form of financing to the traditional bank loan. Bolea and Cosma [14] gave a clear overview of the advantages of leasing, but the study reveals that according to the accountants, not all these advantages equally apply to leasing. Moreover, it also appears that some of the differences between leasing and bank loans that were mentioned in literature do not apply [14]. For example, it appears that there is little difference in the formalities of both forms of financing. The five respondents indicated that, unless specific guarantees are requested by the financial institutions, they would not recommend leasing because there are fewer formalities.

"The formalities are about the same, I think. If you have to give a personal guarantee to the bank, it is of course different from when you don't have to. A separate document has to be drawn up for this and then the formality is of course greater". (A2)

Just as retaining control is not a deciding factor in recommending general financing options, it is also not taken into account when specifically looking at their recommendation for leasing to family businesses, according to our results.

"Banks are more inclined to request interim figures than a leasing company. Leasing companies limit themselves to requesting figures once or not at all. They base themselves on what has been officially filed by the national bank. The guarantee structure is different. They remain the owner of the asset and can simply take it back. Whether this really plays a role in the assessment of the decision, no I don't have that experience". (A1)

The following propositions state that being able to retain control or having fewer formalities have little influence on recommending leasing to family businesses.

Proposition 3 (P3). Accountants tend to not let the family firms' desire to retain control be the decisive factor when recommending leasing as a financing option.

\subsubsection{Risk Aversion}

Family businesses are often considered to be rather risk averse in their (financial) decision making [59]. The accountants confirm that the amount of risk involved in a particular form of financing is indeed taken into account but not considering it as the main decisive factor either.

"I know entrepreneurs who are not concerned with the risk factor; they say I need an investment and I just do it. I also have a case of a family business that is very consciously working on identifying every risk factor". (A4)

The following proposition contains this information about risk aversion when recommending a form of financing. 
Proposition 4 (P4). Accountants tend to take the amount of risk of particular financing forms into consideration but do not consider it as the main differentiating factor when specifically advising family firms with regard to their financing options.

According to family firm literature, it is important to also take into account their riskaversion behavior when making the choice of specific types of financial resources $[10,11]$. Since the focus of this study is related to leasing as financing option, we zoom in on the risk level of this option and the opinion of accountants in this regard. Respondents indicate that leasing is indeed associated with low risk mainly because there are no guarantees since the leased asset is actually the guarantee. Reference [14] also indicated that leasing does not involve a mortgage. This implies that it is considered to be an important financing option to recommend to family firms in particular.

"Low risk: that may be true because with leasing, the company's guarantee is limited to the asset, but if you don't pay off your financing with the bank, they can seize everything. So, in that respect the risk is higher with classic financing options". (A1)

Proposition 5 (P5). Accountants tend to recommend leasing as a form of financing for family firms due to the lower level of risk of this specific financing form.

\subsection{Technical Contingencies}

Besides relational and family-specific elements that are taken into consideration by accountants when advising family firms in their financing decisions, we also look at specific technical elements that might have an impact on the recommendation of accountants. We found that multiple technical elements play a role: the type of asset to be financed, the funding mix, the required flexibility as well as guarantees, and tax drivers.

\subsubsection{Type of Asset and Size of the Investment}

It is noticeable that often, the client already has a few proposals ready concerning the financing options, based on the type of an asset to be financed and the size of the foreseen investment. The respondents unanimously agree that the financing proposed by the company always includes a leasing and a bank loan, at least when it comes to rolling stock.

"Oftentimes, we get this question from a client: I have two proposals here, one from the car dealer and one from the bank. Then they are put next to each other". (A2)

Similar to the research by D'Aurizio et al. [60], accountants also report that in almost every family businesses they work with, traditional financing through the bank is a frequently opted form of financing. According to A3, just like A1 and A5, it depends on the type of asset:

"This depends on the type of asset in question. If financial resources are needed, you will see generally that they mainly opt for bank financing, rather than attracting external financiers. This is a typical feature for family businesses". (A3)

When we look at what proposals are coming from the accountant's side, it is striking that besides bank financing, leasing is often the most prominent, but, indeed, the type of asset and the size of the investment play an important role.

"It depends on the type of asset as well as the amount to be financed. A typical example: cars. In this case, everyone automatically looks in the direction of leasing, but when it comes to buildings or real estate, people look more to classical financing options". (A1)

"Leasing or renting will be encountered mainly in car fleets and very occasionally in real estate". (A3)

Even though, according to the literature, family businesses are reluctant to lease [12], it is remarkable that when family businesses make a financing decision, accountants first consider the bank loan and leasing but also that family businesses sometimes propose 
the leasing option themselves. For family firms, leasing is mainly an option for financing rolling stock, while bank loans are often chosen for financing real estate or other large investments. Therefore, the following proposition is drafted as follows:

Proposition 6 (P6). Accountants tend to recommend leasing as a financing option, they take both the type of asset as well as the size of the investment into account, since also family firms themselves use these decision criteria.

\subsubsection{Funding Mix}

Despite the fact that the bank loan is an important form of financing, according to both the research and the literature $[13,60]$, accountants believe that several options are considered when making a financing decision. In addition, the possibility to make financing mixes, in which different forms of financing are combined, can be a decision driver.

"Certainly, when it comes to larger amounts, a combination of funding options is increasingly being looked at." (A4)

"A bank comes up with a proposal and it is seen as "a sacred thing" and then of course I come and say we are going to do it this way for this reason, or I think it is better to use a bit of the entrepreneur's own contribution or possibly a combination with financing, a combination with leasing. So, I suggest to look at different forms of financing". (A5)

This study did not reveal much about other alternative forms of financing that can be included within such a financing mix. However, some examples were given, such as private equity, sale and leaseback, win-win loans, FFF (family, friends, and fools), and private equity firms.

"In recent years, we have seen more and more the mixed financing phenomena, with, for example, PMV intervening or a European financing fund providing guarantees. The other things that are also coming back more and more are the 'FFF': family, friends, fools and win-win loans". (A4)

From the interviews conducted, it can thus be deduced that various financing options are weighed up against each other but also that these options may be combined because the bank or another investor's advised this. Achieving an optimal capital structure is very complex [61]. Depending on the type of investment or purchase, it is mainly the leasing and traditional bank financing that are chosen. Consequently, we formulate the following proposition:

Proposition 7 (P7). Accountants tend to take the potential combination of funding options into account when considering possible financing options for family businesses, with leasing and bank loans as main elements within such a mix.

\subsubsection{Required Guarantees}

Throughout our interviews, we detected an important element that was indicated by the accountants, namely 'safeguards'. Our literature review mentioned little or nothing about this because its importance in existing research was not particularly high. Nevertheless, it is clear from the interviews that this is a factor with decisive influence for accountants. In all five interviews, the importance of these required guarantees in practice was mentioned.

"Definitely look at the guarantee. If, for example, you or the bank cannot give a guarantee, you can only lease. Then it's: take it or leave it". (A2)

A4 even points out that for family SMEs, (personal) mortgages can sometimes be a determinant. If a bankruptcy occurs, family businesses may be left with nothing. This way of thinking could be explained by the fact that family businesses are characterized by wanting to transfer their assets over generations [59]. The following proposition takes into account the view of accountants on guarantees and states that a form of financing in 
which guarantees are required is preferably avoided by accountants in suggesting financing options for family businesses.

Proposition 8 (P8). Accountants tend to be less inclined to recommend forms of financing that involve a guarantee.

\subsubsection{Monthly Repayments and Interest Rates}

Respondents agree that interest rates play a role when advising on a financing decision, but they are currently quite low, which makes them less relevant within the current time frame. However, the general importance of interest rates in the choice of financing remains very high, and if interest rates rise again, this factor could be decisive.

"Let me give you an example: if proposal A is 1 percent and proposal B is 1.02 percent, then there must actually be a good argument for choosing the 1.02 percent proposal. They often say 'look, you only have to pay so much per month' and then they often make no distinction between what the total repayment is and what the interest is. This often creates a deceptive image. Of course, they always look at the repayment". (A5)

The importance of long-term cash flow is partly related to this. According to the respondents, their customers should not pay high interest rates or have high monthly repayments, because 'Cash is King'.

"Cash is highly important and if you have the ambition as a company to grow, then you should not burn up your cash flow to a large extent on repayments". (A4)

Nevertheless, attracting both sufficient funding and the right sources of finance is not self-evident [62]. For family businesses, the survival of the family dynasty is an important aspect [34], and accountants indicate that the remaining cash flow is needed in the long term to ensure growth and continuity. Unforeseen circumstances such as the COVID-19 crisis can be considered as a good example. The following propositions therefore indicate that the monthly repayments and related interest rates are important when advising on a certain financing option. The accountants consider it to be important that their clients have enough cash flow left over time and do not spend high amounts on interest.

Proposition 9 (P9). Accountants tend to opt for recommending financing options by taking into account the monthly repayment and the interest to be paid of the financing option. They tend to opt for options through which the family firms have enough cash left over to guarantee nonfinancial goals such as firm continuity.

\subsubsection{Tax Drivers}

Tax-related elements appear to be an important factor in recommending particular forms of financing. According to A1, it is important to consider the impact of the financing on the tax aspect. A3, A4, and A5 also indicated that this factor could indeed be reasons to recommend a particular financing option. This also appears to be the case when recommending leasing as an alternative form of financing.

"VAT of course, you don't have to pre-finance it because it happens monthly".

It is noticeable that the tax advantages that leasing used to have are now less significant.

"It is less of a fiscal issue now, but it certainly was in the past. Companies had the possibility with leasing to create a depreciable base more quickly through increased initial invoices: that possibility is still there, but it is being closed down". (A1)

Despite the fact that, according to the accountants, leasing used to have considerable tax advantages, this factor is no longer entirely relevant when recommending leasing. The accountants would choose to recommend leasing because family businesses do not have to prefinance VAT, whereas this is the case with financing through a traditional bank loan because a purchase takes place there [63]. 
Proposition 10 (P10). Accountants tend to take tax aspects into account when advising family firms in their financing options and preferably recommend leasing over traditional bank financing because there is no VAT to prefinance.

\subsubsection{Required Flexibility}

Finally, according to the respondents, there are also several factors related to required flexibility that play a role in recommending certain forms of financing, also with regard to leasing as an option. This broad category is divided into several areas in which flexibility might increase the attractivity of recommending certain financing options.

An important feature of leasing, as also cited by Bolea and Cosma [14], is the general flexibility in comparison with other financing options. Although the accountants confirm that leasing is quite flexible, they state that banks nowadays also offer very flexible forms of financing such as cash loans. For A3, flexibility is the decisive element to recommend leasing, while according to A2, flexibility is limited because of the high cost of terminating a lease.

"With leasing, you do have the opportunity to spread out more: you can say I'm leasing for three years and if you notice that the cash flow doesn't allow this, you can extend it to four years". (A1)

The following proposition has been drafted taking into account that a leasing is flexible [14], for example, because it can be easily extended.

Proposition 11 (P11). Accountants tend to recommend leasing as a possible alternative form of financing because the flexibility is higher than with traditional bank financing.

A second, more specific flexibility reason for which accountants would recommend leasing as a possible alternative form of financing is the avoidance of investment; the lessee does not have to buy the asset and thus avoids investment [14].

"Avoiding a large cash outflow is the main reason for choosing leasing".

However, it should be remembered that accountants have previously indicated that leasing could be an alternative, especially for rolling stock. As both the literature and the respondents confirm that leasing is an attractive form of financing due to the avoidance of investment, the following proposition is made:

Proposition 12 (P12). Accountants tend to choose to recommend leasing to family businesses because it avoids the need to invest, especially investments in, for example, rolling stock, making it a more flexible financing option to recommend.

A third flexibility reason with regard to leasing as a form of financing is related to the flexibility in finally purchasing the asset or not. The literature review already mentioned that the financial lease differs from the operating lease because of the possible purchase option that allows the lessee to buy the asset at the end of the lease at a negotiated price [14]. According to the study, this purchase option is considered convenient and also provides more flexibility. For the respondents, this purchase option is not an immediate reason to encourage family businesses to lease, but it is often included as a possible financing option because they know that the family businesses they work with like to keep the asset within the firm at the end.

"We do not apply much operating leasing options, because the family businesses would like to have that value of the asset at the end of the journey". (A1)

According to existing literature, if family firms can keep assets within their patrimony, they could improve their socioeconomic welfare [12]. For the reason that the purchase option is indirectly important in advice for leasing, the following proposition is formulated: 
Proposition 13 (P13). Accountants tend to recommend financial leasing as it includes a purchase option and provides additional flexibility.

A final argument that is mainly based on flexibility aspects is specifically related to recommending operating or finance leasing within this financing option. Different opinions can be detected on whether to recommend an operating lease or a finance lease. In an operating lease, the lessor assumes all risks so that the lessees do not have to worry about the asset, whereas in a finance lease, the ownership risks lie with the lessee $[14,37]$.

"I usually try to work with off-balance leases for family businesses as much as possible.

Why? It's better in terms of balance sheet presentation and at the end you have that low value purchase option". (A1)

Only A2 indicates that his preference depends on the product and the financial position of the family business. A3 and A4 clearly indicate that they prefer operational leasing to financial leasing, while for A5, it is the other way around because of the purchase option. A1 indicates that he prefers off-balance sheet leasing, but that a purchase option is also possible here. Our research indicates that the other accountants also have experience with operating leases in which a purchase option can be included. It is notable that in practice the definitions of operating leases and finance leases are used interchangeably.

Proposition 14 (P14). Accountants tend to preferably recommend an operating lease, because it involves fewer worries and risks for the family firm and nowadays also offers the possibility of including a purchase option.

It is useful to consider the propositions made in this study as a basis for future research. One could empirically substantiate why these factors influence the financing recommendation and, moreover, to what extent they influence the choice for recommending a lease.

\section{Conclusions}

\subsection{Practical and Theoretical Implications}

This study investigated the role of the accountant as advisor with regard to financing options for family businesses, which factors influence the accountant's decision to recommend a certain financing choice, and especially focusing on leasing as a possible alternative financing form for family businesses. The perspective of the accountant certainly offers added value since, according to the literature, the accountant is considered the most trusted advisor and has a plausible influence on the financial decisions made by family businesses. The research conducted from the accountant's point of view indicates that the accountant takes different factors into account when recommending a financing option for an investment than when the leaders or CEOs of family businesses consider financing options. When deciding whether to recommend a particular financing option, accountants take into consideration relational aspects, family goals and attributes, and technical contingencies. The level of trust family business clients have in the specific expertise of the accountant as trusted advisor in financing options is a crucial determinant [57]. The more the relationship between both parties is trust based, the more influence the accountants have on the financing decisions. This is in line with previous findings in the domain of family business advising [17]. Second, two specific family goals and attributes are often taken into account when accountants formulate recommendations on financing options. Family businesses are driven not only by financial goals but also by multiple nonfinancial, affective goals, captured by the concept of socioemotional wealth [34]. Especially the intent to maintain family control and avoid risk appear to be prevalent factors in the context of financing decisions [58,59]. The accountants in our study highlight an important aspect with regard to family control. They claim that not the control issue itself but rather the power shift toward other parties is an important aspect to take into consideration. Furthermore, they acknowledge that for family business clients, financing options with lower levels of risk, 
is even more important to take into consideration in comparison to nonfamily business clients. Third, multiple technical contingencies appear to form the financing recommendation of the accountants when guiding family businesses in this decision-making process. Here, the type of asset and related size of the investment is an important starting point to form their specific advice. However, a broader viewpoint in terms of funding mixes is an important driver of the specific suggestion of the accountant. Finally, guarantees, tax-related elements, and the level of flexibility of the financing options also form the accountants' recommendations.

Besides driving forces that form the recommendation of accountants, the results of our study also show that with regard to specific financing options, the traditional bank loan and leasing appear to be the two most preferred forms of financing that are suggested by accountants toward their family business clients. However, what are the main advantages of leasing for family businesses? According to the respondents, there are five clear advantages or reasons why this option is regularly recommended by accountants. As just mentioned, ensuring long-term cash flow plays a part in making a financing decision. The first advantage is therefore self-evident and implies that no investment is required when leasing an asset, and therefore no large cash-out is required. This appears to be mainly the case when considering rolling stock. According to the accountants, real estate leasing is rare or nonexistent because traditional bank financing comes first for this type of asset. The second advantage of leasing, i.e. flexibility, is in line with this. The study shows that accountants prefer leasing rolling stock, for example, because it can be performed in the short term but also because it is possible to spread the leasing over a longer period if necessary. This makes it possible to adapt the monthly instalments to the family business' capacities and to purchase or renew the rolling stock at the end of the lease. Because it is a rental contract, leasing does not involve any guarantees. The leased asset remains in the hands of the lessor who can reclaim the asset if financial problems arise. This ensures that the risk with leasing is lower, while the purchase option provides flexibility and convenience. Respondents indicate that this purchase option is often used. The fact that no guarantees apply and that there is the possibility of using the purchase option at the end of the lease contract constitute the third and fourth advantage of leasing, according to the respondents. The last advantage is related to the fiscal aspect. The fiscal advantages that leasing entails according to the accountants, are mainly related to the fact that prefinancing of VAT is required.

The study indicates that for accountants these five arguments are sufficient reasons to recommend leasing as an alternative form of financing for family businesses. Although not much is known in the literature about leasing within family businesses, this study gives an indication that the family businesses with which the respondents work make extensive use of leasing. According to the accountants, leasing is not able to replace traditional bank financing, but it is a possible alternative form of financing, certainly when purchasing specific assets such as rolling stock.

\subsection{Limitations and Recommendations for Further Research}

This study focuses on the role of the accountant in the family firms' decision-making process to use leasing as an alternative form of finance. However, family firm heterogeneity based on firm size and age was not specifically considered. These factors do appear to have an influence on the financial decisions of family businesses [64]. It could therefore be interesting to investigate whether these factors influence the accountant's advice on a particular form of financing and more specific advice on leasing. One could examine whether the accountant in large family businesses recommends leasing more, less, or equally as a possible alternative form of financing.

Unfortunately, the study cannot make a distinction based on the financial positions of family firms. It was mentioned earlier that when there is a possibility of internal financing, this option is preferred within family firms, but if this is no longer possible, they have to look for other financing options [65]. It could therefore be interesting to 
divide family businesses into the degree of internal financing and thus to examine whether family businesses that have many versus few internal financing possibilities are more or less interested in leasing. Moreover, the underlying theory on capital structure in this study is the POT [30] that we integrated with SEW [34]. However, for example, recent research trends on sustainable finance suggest that the classic finance framework (POT versus TOT) might offer an incomplete picture where the profit maximization should be integrated by environmental, social, and governance principles (ESG). That is, future studies could encompass the ESG perspective into the dichotomy between capital structure and family firms.

This investigation, in line with major literature strands, assumes that family owners ponder financial- and emotional-related factors when choosing leasing as an alternative form of financing. Such a trade-off should also be considered by external advisors who should be aware of nonfinancial needs and might discuss with their family business clients multiple options based on, for example, the goal of preserving family control. Whether or not accountants and advisors are cognizant of these issues remains an open question that, due to data limitation, this study cannot help to explore. That is, the awareness of external consultants emerges as a fruitful avenue to investigate in future research efforts.

According to the accountants in this study, the abilities of the firm and the owner/manager play a role in the choice of bank financing. The literature shows that owner/managers indeed have a significant influence on the financing decisions of family firms $[28,66,67]$. According to Di Giuli, Caselli, and Gatti [39], the use of leasing increases across generations but also when the family firm is characterized by an external CFO or shareholder. It is possible that that the accountant's view is different if the family business is led by nonfamily CFO or has external shareholders.

Another topic that was dealt with in more depth was that of 'guarantees'. While collecting and analyzing the data, it became clear that the importance of guarantees in the field of financing is very high. In order to extend this research, one could investigate why, when, and which guarantees are requested from and given by family firms. Subsequently, one could analyze which forms of financing this applies to and how the accountant interprets this. This subject can also be approached from different angles, such as bank directors, CEOs of family businesses, or their advisors.

Author Contributions: Conceptualization, A.M., J.S., P.V., and A.C.; methodology, A.M., J.S., P.V., and A.C.; formal analysis, A.M., J.S., P.V., and A.C.; writing-original draft preparation A.M., J.S., P.V., and A.C.; writing-review and editing, A.M., J.S., P.V., and A.C. All authors have read and agreed to the published version of the manuscript.

Funding: This research received funding from the Flanders Research Foundation-Scientific Research Network on Accounting in Private Firms.

Institutional Review Board Statement: Not applicable.

Informed Consent Statement: Not applicable.

Conflicts of Interest: The authors declare no conflict of interest.

\section{References}

1. Gallo, M.A.; Vilaseca, A. Finance in family business. Fam. Bus. Rev. 1996, 9, 387-401. [CrossRef]

2. Michiels, A.; Uhlaner, L.; Dekker, J. The effect of family business professionalization on dividend payout. J. Small Bus. Enterp. Dev. 2017. [CrossRef]

3. Gomez-Mejia, L.R.; Haynes, K.T.; Nunez-Nickel, M.; Jacobson, K.J.; Moyano-Fuentes, J. Socioemotional wealth and business risks in family-controlled firms: Evidence from Spanish olive oil mills. Admin. Sci. Q. 2007, 52, 106-137. [CrossRef]

4. Schepers, J.; Voordeckers, W.; Steijvers, T.; Laveren, E. Long-Term Orientation as a Resource for Entrepreneurial Orientation in Private Family Firms: The Need for Participative Decision Making. Sustainability 2020, 12, 5334. [CrossRef]

5. Acedo-Ramirez, M.A.; Ayala-Calvo, J.C.; Navarrete-Martinez, E. Determinants of Capital Structure: Family Businesses versus Non-Family Firms. Czech J. Econ. Financ. 2017, 67, 80-103.

6. Andres, C. Family ownership, financing constraints and investment decisions. Appl. Financ. Econ. 2011, 21, 1641-1659. [CrossRef]

7. Colli, A. Family firms between risks and opportunities: A literature review. Socio Econ. Rev. 2013, 11, 577-599. [CrossRef] 
8. Blanco-Mazagatos, V.; de Quevedo-Puente, E.; Castrillo, L.A. The trade-off between financial resources and agency costs in the family business: An exploratory study. Fam. Bus. Rev. 2007, 20, 199-213. [CrossRef]

9. Berger, A.N.G.; Udell, F. The Economics of Small Business Finance: The Roles of Private Equity and Debt Markets in the Financial Growth Cycle. J. Bank. Financ. 1998, 22, 613-673. [CrossRef]

10. Gonzalez, M.; Guzman, A.; Pombo, C.; Trujillo, M.A. Family firms and debt: Risk aversion versus risk of losing control. J. Bus. Res. 2013, 66, 2308-2320. [CrossRef]

11. Burgstaller, J.; Wagner, E. How do family ownership and founder management affect capital structure decisions and adjustment of SMEs? Evidence from a bank-based economy. J. Risk Financ. 2015. [CrossRef]

12. Landry, S.; Fortin, A.; Callimaci, A. Family firms and the lease decision. J. Fam. Bus. Strateg. 2013, 4, 176-187. [CrossRef]

13. Chua, J.H.; Chrisman, J.J.; Kellermanns, F.; Wu, Z. Family involvement and new venture debt financing. J. Bus. Ventur. 2011, 26, 472-488. [CrossRef]

14. Bolea, A.; Cosma, R. Leasing as a modern form of business financing. Prog. Econ. Sci. 2015. [CrossRef]

15. Mol-Gómez-Vázquez, A.; Hernández-Cánovas, G.; Koëter-Kant, J. The use of leasing in financially constrained firms: An analysis for european SMEs. Czech J. Econ. Financ. 2019, 69, 538-557.

16. Michiels, A.; Molly, V. Financing decisions in family businesses: A review and suggestions for developing the field. Fam. Bus. Rev. 2017, 30, 369-399. [CrossRef]

17. Strike, V.M. Advising the family firm: Reviewing the past to build the future. Fam. Bus. Rev. 2012, 25, 156-177. [CrossRef]

18. Strike, V.M.; Michel, A.; Kammerlander, N. Unpacking the black box of family business advising: Insights from psychology. Fam. Bus. Rev. 2018, 31, 80-124. [CrossRef]

19. Reay, T.; Pearson, A.W.; Gibb Dyer, W. Advising Family Enterprise: Examining the Role of Family Firm Advisors; Sage Publications: Los Angeles, CA, USA, 2013.

20. Strike, V.M.; Rerup, C. Mediated sensemaking. Acad. Manag. J. 2016, 59, 880-905. [CrossRef]

21. Barbera, F.; Hasso, T. Do we need to use an accountant? The sales growth and survival benefits to family SMEs. Fam. Bus. Rev. 2013, 26, 271-292. [CrossRef]

22. Nicholson, H.; Shepherd, D.; Woods, C. Advising New Zealand's family businesses: Current issues and opportunities. Univ. Auckl. Bus. Rev. 2009, 11, 12.

23. Reay, T. Publishing Qualitative Research; Sage Publications: Los Angeles, CA, USA, 2014.

24. De Massis, A.; Kotlar, J. The case study method in family business research: Guidelines for qualitative scholarship. J. Fam. Bus. Strateg. 2014, 5, 15-29. [CrossRef]

25. Zhang, K.Q.; Chen, H.H. Environmental performance and financing decisions impact on sustainable financial development of Chinese environmental protection enterprises. Sustainability 2017, 9, 2260. [CrossRef]

26. Barton, S.; Mathews, C. ÔSmall Firm Financing: Implications from a Strategic Management Perspective. J. Small Bus. Manag. 1989, 27, 1-7.

27. McMahon, R.G.; Stanger, A.M. Understanding the small enterprise financial objective function. Entrep. Theory Pract. 1995, 19, 21-39. [CrossRef]

28. Feltham, T.S.; Feltham, G.; Barnett, J.J. The dependence of family businesses on a single decision-maker. J. Small Bus. Manag. 2005, 43, 1-15. [CrossRef]

29. Gallo, M.Á.; Tàpies, J.; Cappuyns, K. Comparison of family and nonfamily business: Financial logic and personal preferences. Fam. Bus. Rev. 2004, 17, 303-318. [CrossRef]

30. Myers, S.C. Capital Structure Puzzle; National Bureau of Economic Research: Cambridge, MA, USA, 1984.

31. Brennan, M.J.; Schwartz, E.S. Corporate income taxes, valuation, and the problem of optimal capital structure. J. Bus. 1978, 51, 103-114. [CrossRef]

32. Gottardo, P.; Moisello, A.M. The capital structure choices of family firms: Evidence from Italian medium-large unlisted firms. Manag. Financ. 2014, 40, 254-275. [CrossRef]

33. Bacci, S.; Cirillo, A.; Mussolino, D.; Terzani, S. The influence of family ownership dispersion on debt level in privately held firms. Small Bus. Econ. 2018, 51, 557-576. [CrossRef]

34. Gomez-Mejia, L.R.; Cruz, C.; Berrone, P.; De Castro, J. The bind that ties: Socioemotional wealth preservation in family firms. Acad. Manag. Ann. 2011, 5, 653-707. [CrossRef]

35. Caprio, L.; Croci, E.; del Giudice, A. Ownership structure, family control, and acquisition decisions. J. Corp. Financ. 2011, 17, 1636-1657. [CrossRef]

36. Procházka, D. The Impact of Globalization on International Finance and Accounting; Springer: Berlin/Heidelberg, Germany, 2018.

37. Lee, K. Capital and Operating Leases; Federal Accounting Standards Advisory Board: Washington, DC, USA, 2003.

38. Krishnan, V.S.; Moyer, R.C. Bankruptcy costs and the financial leasing decision. Financ. Manag. 1994, 23, 31-42. [CrossRef]

39. Di Giuli, A.; Caselli, S.; Gatti, S. Are small family firms financially sophisticated? J. Bank. Financ. 2011, 35, 2931-2944. [CrossRef]

40. Chua, J.H.; Chrisman, J.J.; Sharma, P. Defining the Family Business by Behavior. Entrep. Theory Pract. 1999, 23. [CrossRef]

41. Kaye, K.; Hamilton, S. Roles of trust in consulting to financial families. Fam. Bus. Rev. 2004, 17, 151-163. [CrossRef]

42. Mathile, C.L. A business owner's perspective on outside boards. Fam. Bus. Rev. 1988, 1, 231-237. [CrossRef]

43. Budge, G.S.; Janoff, R.W. Interpreting the discourses of family business. Fam. Bus. Rev. 1991, 4, 367-381. [CrossRef] 
44. Tout, S.; Ghazzawi, K.; El Nemar, S.; Choughari, R. The major role accountants play in the decision making process. Int. J. Financ. Acc. 2014, 3, 310-315.

45. Schulze, W.S.; Lubatkin, M.H.; Dino, R.N.; Buchholtz, A.K. Agency relationships in family firms: Theory and evidence. Organ. Sci. 2001, 12, 99-116. [CrossRef]

46. Berry, A.J.; Sweeting, R.; Goto, J. The effect of business advisers on the performance of SMEs. J. Small Bus. Enterp. Dev. 2006. [CrossRef]

47. Eisenhardt, K.M.; Graebner, M.E. Theory building from cases: Opportunities and challenges. Acad. Manag. J. 2007, 50, 25-32. [CrossRef]

48. Baarda, B.; Bakker, E.; Fischer, T.; Julsing, M.; Peters, V.; van der Velden, T.; de Goede, M. Basisboek Kwalitatief Onderzoek: Handleiding voor het Opzetten en Uitvoeren van Kwalitatief Onderzoek; Noordhoff Uitgevers: Groningen, The Netherlands, 2013.

49. Eisenhardt, K.M. Building theories from case study research. Acad. Manag. Rev. 1989, 14, 532-550. [CrossRef]

50. Glaser, B.G.; Strauss, A.L. Discovery of Grounded Theory: Strategies for Qualitative Research; Routledge: Milton Park, UK, 2017.

51. Sobal, J. Sample extensiveness in qualitative nutrition education research. J. Nutr. Educ. 2001, 33, 184-192. [CrossRef]

52. Everaert, P.; Sarens, G.; Rommel, J. Sourcing strategy of Belgian SMEs: Empirical evidence for the accounting services. Prod. Plan. Control 2007, 18, 716-725. [CrossRef]

53. Westhead, P.; Cowling, M. Family firm research: The need for a methodological rethink. Entrep. Theory Pract. 1998, $23,31-33$. [CrossRef]

54. Tracy, S.J. Qualitative quality: Eight “Big-tent" criteria for excellent qualitative research. Qual. Inq. 2010, 16, 837-851. [CrossRef]

55. Gustafsson, Å. Assessing work order information quality in harvesting. Silva. Fenn. 2017, 51, 1-18. [CrossRef]

56. Yin, R.K. Qualitative Research from Start to Finish; Guilford Publications: New York, NY, USA, 2015.

57. Chrisman, J.J.; Chua, J.H.; Kellermanns, F.W.; Chang, E.P.C. Are family managers agents or stewards? An exploratory study in privately held family firms. J. Bus. Res. 2007, 60, 1030-1038. [CrossRef]

58. Molly, V.; Laveren, E.; Jorissen, A. Intergenerational differences in family firms: Impact on capital structure and growth behavior. Entrep. Theory Pract. 2012, 36, 703-725. [CrossRef]

59. López-Gracia, J.; Sánchez-Andújar, S. Financial structure of the family business: Evidence from a group of small Spanish firms. Fam. Bus. Rev. 2007, 20, 269-287. [CrossRef]

60. D'Aurizio, L.; Oliviero, T.; Romano, L. Family firms, soft information and bank lending in a financial crisis. J. Corp. Financ. 2015, 33, 279-292. [CrossRef]

61. Orlova, S.; Harper, J.T.; Sun, L. Determinants of capital structure complexity. J. Econ. Bus. 2020, 110, 105905. [CrossRef]

62. Koropp, C.; Kellermanns, F.W.; Grichnik, D.; Stanley, L. Financial decision making in family firms: An adaptation of the theory of planned behavior. Fam. Bus. Rev. 2014, 27, 307-327. [CrossRef]

63. Smith Jr, C.W.; Wakeman, L.M. Determinants of corporate leasing policy. J. Financ. 1985, 40, 895-908. [CrossRef]

64. Serrasqueiro, Z.; Nunes, P.M.; da Silva, J.V. The influence of age and size on family-owned firms' financing decisions: Empirical evidence using panel data. Long Range Plan. 2016, 49, 723-745. [CrossRef]

65. Carpenter, R.E.; Petersen, B.C. Is the growth of small firms constrained by internal finance? Rev. Econ. Stat. 2002, 84, 298-309. [CrossRef]

66. Kelly, L.M.; Athanassiou, N.; Crittenden, W.F. Founder centrality and strategic behavior in the family-owned firm. Entrep. Theory Pract. 2000, 25, 27-42. [CrossRef]

67. Carbone, E.; Cirillo, A.; Saggese, S.; Sarto, F. IPO in family business: A systematic review and directions for future research. J. Fam. Bus. Strateg. 2021. [CrossRef] 